\title{
Production factors affecting antioxidant peptides from tilapia processing byproducts
}

\author{
Kwanruedee WACHIRATTANAPONGMETEE ${ }^{1}$, Somporn KATEKAEW ${ }^{2}$, Amporn SAE-EAW ${ }^{1}$, \\ Supawan THAWORNCHINSOMBUT ${ }^{1 *}$
}

\begin{abstract}
This research aimed to elucidate significant factors affecting antioxidant capacity of protein hydrolysates from tilapia processing byproducts. Effects of protein type, substrate concentration (0.4-1.2\%) and time of hydrolysis (0-60 min) on antioxidant abilities were investigated. Antioxidant activity of the alkaline-aided protein hydrolysate (APH) hydrolyzed by Protease G6 at $1.2 \%$ and 60 min hydrolysis was comparable to the control (minced tilapia muscle hydrolysates) and was more effective than the myofibrillar protein and sarcoplasmic protein hydrolysates. Principal component analysis showed that the APH exert their antioxidant capacity by peroxyl radical quenching ability. These findings provide evidence that the APH from fish byproducts can be alternatively used as a natural antioxidant.
\end{abstract}

Keywords: tilapia byproducts; myofibrillar protein; sarcoplasmic protein; alkaline-aided protein hydrolysate; natural antioxidant.

Practical Application: The alkaline-aided proteins were recovered from fish byproducts revealing antioxidant capacity after being hydrolysis under suitable conditions. The alkaline-aided protein hydrolysates (APH) hydrolyzed by Protease G6 can be used as a valuable and low-cost source for a natural antioxidant for human consumption.

\section{Introduction}

Byproducts from fish processing waste have attracted considerable attention especially for protein hydrolysate production. In 2016, the farmed Nile tilapia (Oreochromis niloticus) production in Thailand was about $176,400 \mathrm{MT}$ and the export volume was 7,975 MT with around $38.1 \%$ exported as chilled and frozen fillet. Approximately 50-70\% byproducts are generated from the filleting process of tilapia (Subdivision of Research and Analysis of Fisheries Statistics, 2017). With around 35\% crude protein (dry basis), the tilapia byproducts can be used as a valuable and low-cost source for human food proteins.

Due to the harmful effects on consumer health, human consumption of synthetic antioxidants is restricted in many countries. Accordingly, several researchers have made more efforts to discover alternative natural antioxidants including antioxidant peptides and their possible use in food products (Hraš et al., 2000). Protein hydrolysates from aquatic food byproducts have been reported to exhibit antioxidant properties (García-Moreno et al., 2014; Chi et al., 2015). Peptides derived from suitably hydrolyzed traditional tilapia also showed a specific bioactivity or multi-functional bioactivities (Dekkers et al., 2011). Various factors such as protein source, substrate concentration, enzyme type as well as condition of hydrolysis have been extensively reported to influence functionalities and bioactivities of fish protein hydrolysates. However, information regarding the comparison of antioxidant peptides derived from different protein types extracted from fish byproducts is limited. Isoelectric solubilisation-precipitation is an efficient process to recover protein from fish byproducts with high yield and simultaneously removes lipids and other impurities (skin, bone, scale, and connective tissue etc.) (Hultin \& Kelleher, 1999). The obtained protein extract contains both myofibrillar and sarcoplasmic proteins, which would yield different antioxidant activity from each protein alone after being hydrolyzed.

The research objectives were to evaluate the effects of various protein types (sarcoplasmic, myofibrillar and alkali-aided extracted proteins from the tilapia byproducts), substrate concentration and time of hydrolysis on antioxidant properties of protein hydrolysates and to correlate them using principal component analysis (PCA).

\section{Materials and methods}

\subsection{Materials}

Frozen Nile tilapia fillet and byproducts (TB) including trimmed meat, belly flap meat, fin and head-frame were purchased from Grobest Thailand, Co., Ltd. (Nakhonphanom province, Thailand). The samples (in polyethylene bags) were stored with ice in a polystyrene box and transported by a temperature controlled truck $\left(-12 \pm 2{ }^{\circ} \mathrm{C}\right)$ to the Department of Food Technology, Khon Kaen University, within 5-6 h. Protease G6 (DuPont" Genencor Science, USA, a commercial alkaline endopeptidase from Bacillus licheniformis with a declared activity of 580,000 DU/g) was purchased from Siam Victory Chemicals Co., Ltd, Thailand.

${ }^{1}$ Department of Food Technology, Faculty of Technology, Khon Kaen University, Khon Kaen 40002, Thailand

${ }^{2}$ Department of Biochemistry, Faculty of Science, Khon Kaen University, Khon Kaen 40002, Thailand

${ }^{*}$ Corresponding author: suptha@kku.ac.th 


\subsection{Preparation of protein extracts}

Both frozen tilapia fillet (control) and tilapia byproducts (TB) (head-frame, fin, trimmed meat and belly flap meat) were cut into pieces (about $1 \times 1 \mathrm{inch}^{2}$ ) after thawing (at $5^{\circ} \mathrm{C}$, $1 \mathrm{~h}$ ), and then minced by grinder with $5 \mathrm{~mm}$ diameter sieve (BIRO 8-22 E97, The BIRO MFG. Co., USA). All of TB types were mixed in 1:1:1:1 ratio (w:w:w:w) for $30 \mathrm{~s}$ (Crypto Peerless 10, Crypto Peerless LTD., France). Moisture contents of the fillet and mixed TB were $79.3 \%$ and $59.4 \%$, respectively. Other compositions i.e. protein, fat, and ash contents of the fillet and mixed TB were 77.4 and $43.0 \%, 12.5$ and 53.5\%, 5.2 and $8.7 \%$ (dry basis), respectively (Association of Official Analytical Chemists, 1999). After freeze drying (Freeze Dryer, Alpha 2-4 LD plus, Martin Christ, Germany), the mixed TB and fillet (control) powders were vacuum-packed (Henkovac Table Top 1500, Europac Co., LTD., Netherlands) in an aluminum foil bag and kept at $-30{ }^{\circ} \mathrm{C}$ until used for protein extraction.

For the sarcoplasmic protein (SP) and myofibrillar protein (MP) extractions (Dyer et al., 1950 with slight modification), the TB powder was homogenized (Ace, Nihonseiki Kaisha Co., Japan) with 5 parts of sodium phosphate buffer ( $50 \mathrm{mM}, \mathrm{pH} 7.0$ ) and with 7 parts of $0.6 \mathrm{M} \mathrm{NaCl}$ solution in sodium phosphate buffer (50 mM, pH 7.0), respectively. The supernatants were collected and freeze dried (Freeze dryer, Alpha 2-4 LD plus, Martin Christ, Germany). The alkali-aided extracted protein (AP) was prepared from the TB using the method of Hultin \& Kelleher (1999) with slight modifications. In brief, TB powder was mixed with cold deionized water (1:9) and homogenized at 8,000 rpm for $1 \mathrm{~min}$ (at $4^{\circ} \mathrm{C}$ ). The protein solubilization was conducted at $\mathrm{pH} 11.0$ using $2 \mathrm{~N} \mathrm{NaOH}$ (digital pH meter, Mettler-Toledo FE20-I, Switzerland). After centrifugation (10,000 x g, $20 \mathrm{~min}$, $4{ }^{\circ} \mathrm{C}$ ), the attained supernatant was adjusted to 5.5 using $2 \mathrm{~N}$ $\mathrm{HCl}$ to precipitate proteins. The protein concentrate (sediment) was adjusted to pH 7.0 with $50 \mathrm{mM}$ sodium phosphate buffer and lyophilized. The three protein extracts powders were each vacuum-packed in an aluminum foil bag and kept at $-30{ }^{\circ} \mathrm{C}$ until used.

\subsection{Preparation of protein hydrolysates}

The three lyophilized protein extracts and minced fillet (control) were hydrolyzed by Protease G6. Effect of hydrolysis times (0-60 $\mathrm{min})$ and substrate concentrations $(0.4,0.6,0.8,1.0 \& 1.2 \%)$ on antioxidant activities were determined. Other hydrolysis conditions were fixed at $1.5 \mathrm{ml}$ Protease G6/100 g protein (E/S), pH 9.5 (glycine- $\mathrm{NaOH}$ buffer), and $65^{\circ} \mathrm{C}$ in water bath (Comfort, Heto Master Shake, France). These hydrolysis conditions were chosen according to the preliminary experiment by varying $\mathrm{pHs}$ (7.0-10.0) and temperatures $\left(25-65^{\circ} \mathrm{C}\right)$ of hydrolysis to obtain the highest degree of hydrolysis and protein content. The reaction was inactivated by immersion in boiling water for $10 \mathrm{~min}$. After being cooled and centrifuged (1-15 K, Higher-Speed Benchtop Microcentrifuge, Sigma-Sartorius, Germany), the supernatant was removed and filtered through $0.22 \mu \mathrm{m}$ membrane. The aliquot of protein hydrolysate solution was kept at $4{ }^{\circ} \mathrm{C}$ until analyzed.

\subsubsection{The release of TCA soluble peptides}

The releases of trichloroacetic acid (TCA) soluble peptides during hydrolysis were determined (Hoyle \& Merritt, 1994, with slight modifications). An aliquot of the hydrolysate taken at $0,5,10,15,30$, and 60 min was mixed with $20 \%$ TCA solution to a final concentration of $10 \%$. The mixture was stood for $30 \mathrm{~min}$ and centrifuged at $10,000 \mathrm{xg}$ for $15 \mathrm{~min}\left(4^{\circ} \mathrm{C}\right)$. The total soluble protein content was determined using an automatic microtiter plate spectrophotometer (Varioskan flash reader, Thermo fisher, Finland) (Fryer et al., 1986) as described in 2.3.2.

The rate of TCA soluble peptides released was calculated according to this equation:

Rate of soluble peptide released $(\mathrm{mg} / \mathrm{ml} / \mathrm{min})=$ [protein content in $10 \%$ TCA at $\mathrm{t}$ min - protein content in $10 \% \mathrm{TCA}$ at $0 \mathrm{~min}] / \mathrm{t}$

when $\mathrm{t}=$ time at the hydrolysate taken to be analyzed $(\mathrm{min})$.

\subsubsection{Protein content in protein hydrolysates}

Fryer et al. (1986) described a Lowry protein assay using an automatic microtiter plate spectrophotometer. One hundred microliters of protein hydrolysate were pipetted into each well of a flat bottom polystyrene 96-well plate (flat bottom polystyrene without lid and sterile (Corning, USA)) and $25 \mu$ l solution C $\left(10 \% \mathrm{Na}_{2} \mathrm{CO}_{3}\right.$ in $0.5 \mathrm{~N} \mathrm{NaOH} ; 10 \% \mathrm{~K}$, Na-tartrate; $5 \% \mathrm{Cu}_{2} \mathrm{SO}_{4}$ ) was added, then mixed for 30 s using plate-shaker and incubated for $10 \mathrm{~min}$ at room temperature. Ten $\mu$ l of solution $\mathrm{D}(1 \mathrm{~N}$, Folin-Ciocalteu phenol reagent) were added to each well and mixed for 30s. The reaction was incubated for $20 \mathrm{~min}$ at room temperature in the dark and then the absorbance was read at $750 \mathrm{~nm}$ by the multi-mode microplate reader. Bovine serum albumin was used to establish a standard curve.

\subsubsection{Oxygen Radical Absorbance Capacity (ORAC) assay}

The hydrophilic- and lipophilic-ORAC values of protein hydrolysates were analyzed according to the method of Huang et al. (2002) with some modifications. Freshly diluted fluorescein disodium (FL) in $75 \mathrm{mM}$ phosphate buffer ( $\mathrm{pH} 7.4)$ was prepared before adding to sample or standard. In the hydrophilic-ORAC, $75 \mathrm{mM}$ phosphate buffer ( $\mathrm{pH}$ 7.4) was used as a solubilizing medium. For the lipophilic-ORAC assay, sample and standard were diluted with the $7 \%$ randomly methylated $\beta$-cyclodextrin (RMCD) made in a $50 \mathrm{ml} / 100 \mathrm{ml}$ acetone-water.

The $25 \mu$ diluted samples or standards (trolox) were added with the FL working solution $(120 \mu \mathrm{M}, 175 \mu \mathrm{l})$ in each well of a 96-well black plate and pre-incubated at $37^{\circ} \mathrm{C}$ for $15 \mathrm{~min}$. Fifty $\mu \mathrm{l}$ for hydrophilic or $75 \mu \mathrm{l}$ for lipophilic of $65.5 \mathrm{mM}$ AAPH (2,2'-azobis (2-amidinopropane)) was added into each well using automatic dispenser to activate the reaction. The AAPH was freshly prepared in $75 \mathrm{mM}$ phosphate buffer $(\mathrm{pH} 7.4)$ to generate free radicals for each run of assay. The fluorescence excitation/emission was performed at 485/530 nm. The FL intensity changes representing the peroxyl radicals inhibition was instantly recorded at $1 \mathrm{~min}$ interval for $35 \mathrm{~min}$, at $37^{\circ} \mathrm{C}$ in the multi-mode microplate reader. Phosphate buffer $(75 \mathrm{mM}$, $\mathrm{pH}$ 7.4) was used as a negative control and subtracted from each 
peroxyl-treated sample (the net area under the fluorescence decay curve; net AUC).

The ORAC values ( $\mathrm{mg}$ trolox equivalents per $100 \mu \mathrm{g}$ BSA) were obtained from plotting a series of trolox concentrations $(0-100 \mu \mathrm{g} / \mathrm{ml} ; \mathrm{y})$ and the net AUC $(\mathrm{x})$ using a linear regression equation $(y=a x+b)(C a o \&$ Prior, 1999).

\subsubsection{ABTS radical cation decolorization (ABTS) assay}

The ABTS radical scavenging activity of protein hydrolysates were estimated following the method of Arnao et al. (2001). The ABTS radical cation $\left(\mathrm{ABTS}^{+}\right)$was generated by the reaction between $7.4 \mathrm{mM}$ ABTS solution and $2.6 \mathrm{mM}$ potassium persulfate in the dark at room temperature for $12-16 \mathrm{~h}$. The fresh $\mathrm{ABTS}^{+\cdot}$ working solution was prepared by diluting $1 \mathrm{ml}$ of $\mathrm{ABTS}^{+*}$ solution with $53 \mathrm{ml}$ of phosphate buffer (10 mM, pH 7.4) containing $0.15 \mathrm{M}$ $\mathrm{NaCl}$ to an absorbance reading of $1.1 \pm 0.02$ units $(734 \mathrm{~nm})$. The reaction between the protein hydrolysate or trolox as a standard $(25 \mu \mathrm{l})$ and the diluted ABTS ${ }^{+\bullet}$ solution $(200 \mu \mathrm{l})$ took place in the dark for $2 \mathrm{~h}$. Reduction of blue-green ABTS radical colored solution was then recorded at $734 \mathrm{~nm}$ using the microplate reader. The ABTS radical scavenging activity was calculated from a standard curve of trolox ranging from 0 to $60 \mu \mathrm{g} / \mathrm{ml}$ and expressed as mg trolox equivalent per $100 \mu \mathrm{g}$ BSA.

\subsubsection{Assay of metal ion chelation}

The method of Boyer \& McCleary (1987) was modified to measure the metal chelating ability of protein hydrolysates. Five $\mu \mathrm{l}$ of $4 \mathrm{mM} \mathrm{Fe}_{2} \mathrm{SO}_{4}$ were added to $150 \mu \mathrm{l}$ of sample solutions and blank (distilled water) in a microplate. Subsequently, the mixture was added with $10 \mu \mathrm{l}$ of $10 \mathrm{mM}$ ferrozine (3-(2-pyridyl)5,6-bis(4-phenyl-sulfonic acid)-1,2,4-triazine) at room temperature for $30 \mathrm{~min}$. The absorbance of the reaction was read at $562 \mathrm{~nm}$ using the microplate reader. EDTA was taken as the standard. The chelating activity was expressed as mg EDTA per $100 \mu \mathrm{g}$ protein.

\subsection{Statistical analysis}

Analysis of variance (ANOVA) was carried out and mean comparison was determined by Duncan's multiple range test $(\mathrm{DMRT})$ at the $95 \%$ significant level $(\mathrm{P}<0.05)$ using SPSS statistical program, version 19. Two replications of experiment were performed and all analyses were carried out in (at least) triplicate.

To find out the percentage of the variance explaining the factors (protein types, substrate concentration and hydrolysis time) that influence the antioxidant activity of protein hydrolysates, principal component analysis (PCA) was performed by XLSTAT program, version 2017.

\section{Results and discussion}

\subsection{Antioxidant properties of TB protein hydrolysates}

The use of different hydrolysis conditions should release peptides with various abilities, chain sizes and chemical compositions. ANOVA test represents effects of factors and their interactions on protein content and antioxidant activities of hydrolysates (Table 1). In general, all factors have significant effects on all responses. An interaction effect of protein type and substrate concentration was found in ABTS assay, metal chelating ability and release of TCA soluble peptides $(P<0.05)$. The metal chelating ability and release of TCA soluble peptides were also influenced by interaction effect of protein type and hydrolysis time $(\mathrm{P}<0.05)$.

The high release of TCA soluble peptides showed a high release of peptide fragments. The protein content of APH was higher than other hydrolysates (Table 2), which was agreed with its highest degree of hydrolysis considered as the release of peptides during hydrolysis (Figure 1). The MP showed the lowest rate of hydrolysis possibly because it contained high $\mathrm{NaCl}$ content used in the extraction process resulting in $\sim 1.5 \mathrm{M} \mathrm{NaCl}$ in the MP powder after freeze drying. It has been known that protein becomes aggregates at high salt concentration (salting out effect) (Nelson \& Cox, 2001), thus being more difficult to be accessed by protease. All proteins were dramatically hydrolyzed during the first 15 min of incubation and being constant afterward. The lower hydrolysis degree of SPH was concomitant with the study by Toopcham et al. (2017) in tilapia muscle proteins. Their explanation was that sarcoplasmic proteins contained protease inhibitors with ability of serine protease inhibition. Thus, the Protease G6, an alkaline serine endopeptidase, used in our research might be partially inhibited during the hydrolysis of SP. The alkali-aided extracted proteins was experienced chemical unfolding, thus it might be more exposed for protease to attack. Wachirattanapongmetee et al. (2009) reported the higher degree

Table 1. ANOVA test representing effects of factors and their interactions on protein content and antioxidant activities of protein hydrolysates.

\begin{tabular}{ccccccc}
\hline Factor ${ }^{1}$ & Protein content & ABTS assay & $\begin{array}{c}\text { Hydrophilic } \\
\text {-ORAC }\end{array}$ & $\begin{array}{c}\text { Lipophilic -ORAC } \\
\begin{array}{c}\text { Metal chelating } \\
\text { ability }\end{array}\end{array} \begin{array}{c}\text { Release of TCA } \\
\text { soluble peptides }\end{array}$ \\
\hline $\mathbf{P}$ & 0.000 & 0.304 & 0.014 & 0.001 & 0.000 & 0.000 \\
{$[\mathbf{S}]$} & 0.000 & 0.000 & 0.000 & 0.000 & 0.000 & 0.000 \\
$\mathbf{t}$ & 0.000 & 0.000 & 0.000 & 0.000 & 0.000 & 0.000 \\
$\mathbf{P}{ }^{*}[\mathbf{S}]$ & 0.794 & 0.025 & 0.148 & 0.989 & 0.000 & 0.000 \\
$\mathbf{P}{ }^{*} \mathbf{t}$ & 0.588 & 0.927 & 0.982 & 1.000 & 0.318 & 0.075 \\
{$[\mathbf{S}]^{*} \mathbf{t}$} & 0.998 & 0.972 & 0.999 & 1.000 & 1.000 & 1.000 \\
$\left.\mathbf{P}{ }^{*} \mathbf{S}\right]^{*} \mathbf{t}$ & 1.000 & 1.000 & 1.000 &
\end{tabular}

${ }^{1} \mathrm{P}$ : Type of protein (freeze dried minced fillet, control; alkali-aided extracted protein, AP; myofibrillar protein, MP; and sarcoplasmic protein, SP); [S]: Substrate concentration (0.4, $0.6,0.8,1.0$ and $1.2 \%)$; t: Time of hydrolysis $(0,5,10,15,30$ and $60 \mathrm{~min})$. 
Table 2. Effect of protein type on antioxidant activities and protein content of protein hydrolysates.

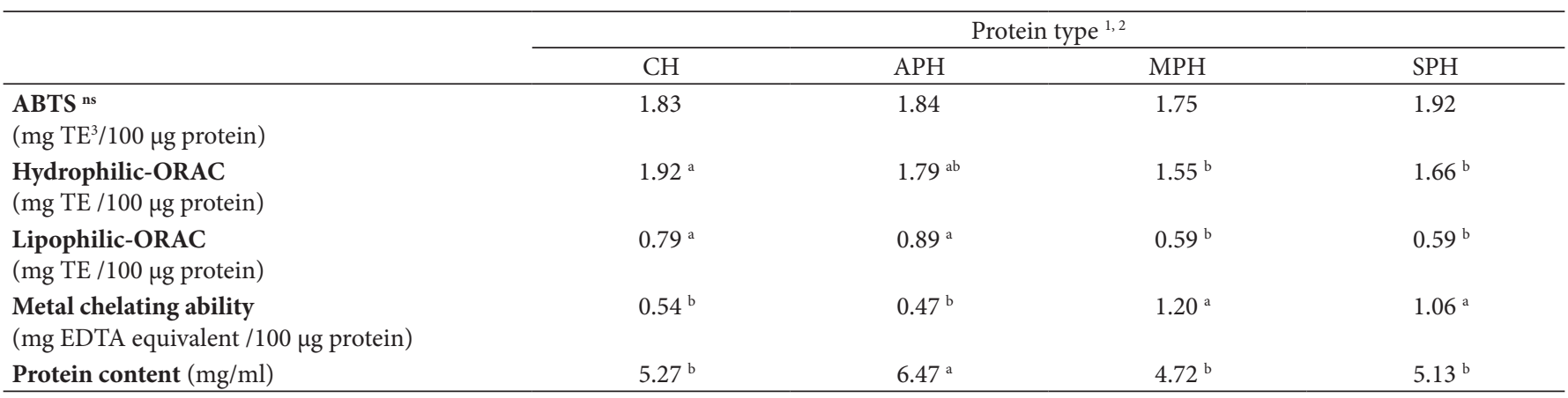

${ }^{1} \mathrm{CH}, \mathrm{APH}, \mathrm{MPH}, \&$ SPH: Hydrolysates of freeze dried minced fillet, alkali-aided extracted proteins, myofibrillar protein extract, and sarcoplasmic protein extract, respectively. ${ }^{2}$ Each value is the average of each measurement analyzed from all substrate levels and hydrolysis times of the same protein type. Different letters within each row indicate a significant difference $(\mathrm{P}<0.05)$ among treatments. $\mathrm{ns}=$ non-significance at the 0.05 probability level. ${ }^{3} \mathrm{TE}$ : Trolox equivalent.

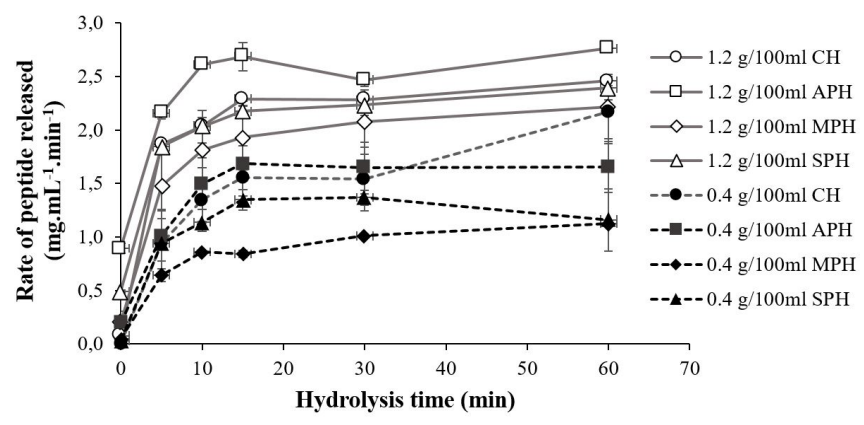

Figure 1. The release of soluble peptides of various protein types hydrolyzed by Protease G6 at selected substrate concentration (0.4 and 1.2\%). $\mathrm{CH}, \mathrm{APH}, \mathrm{MPH}$, and $\mathrm{SPH}$; Hydrolysates of freeze dried minced fillet, alkali-aided extracted proteins, myofibrillar protein extract, and sarcoplasmic protein extract, respectively. Values expressed as mean of duplicates (each in triplicate) \pm standard deviation.

of hydrolysis of alkali-extracted proteins obtained from hybrid catfish frame compared to that of the control (minced hybrid catfish frame). These results demonstrated that different types of protein and preparation methods have different susceptibility to proteolysis.

Antioxidant activities of protein hydrolysates were influenced by the protein type used in hydrolysis (Table 2). The two ORAC assays used in this study allowed to monitor the antioxidant efficiency of both lipophilic and hydrophilic compounds in the protein hydrolysates independently by quenching the similar peroxyl free radical (Wu et al., 2003). The lipophilic-ORAC were typically lower in all samples compared to hydrophilic-ORAC (Table 2-4) indicating the protein hydrolysates are more efficient in an aqueous system. Higher antioxidant potency regarding both hydrophilic and lipophilic ORAC assays of the control hydrolysates $(\mathrm{CH})$ and $\mathrm{AP}$ hydrolysates $(\mathrm{APH})$ was notified. In contrast, MP and SP hydrolysates (MPH \& SPH) showed higher metal chelating ability than APH and $\mathrm{CH}(\mathrm{P}<0.05)$. When comparing the antioxidant activities of all assays between $\mathrm{MPH}$ and $\mathrm{SPH}$, they were comparable (Table 2). Chen et al. (2015) stated that $\mathrm{SPH}$ exhibited strongest antioxidant properties including DPPH, hydroxyl, superoxide anion radicals scavenging abilities and the total reducing power when compared with myofibrillar and stroma proteins from tilapia. Nevertheless, in this research, the fresh tilapia mince was used for the protein extractions unlike which, the freeze-dried tilapia byproducts were employed in our work. In addition, the protein hydrolysis was carried out from freeze-dried protein extracts whereas Chen and coworkers' hydrolysates were prepared from protein extract solutions and different protease. Thus, with different process and enzyme used, different results were observed. Wang et al. (2013) reported the comparable ${ }^{\circ} \mathrm{OH}$ scavenging activities of sarcoplasmic and myofibrillar protein hydrolysates from grass carp digested with Alcalase 2.4L. The discrepancy of these findings could be explained by the differences in substrate, protease type as well as enzyme-to-substrate ratio, all of which were directly affect the extent of hydrolysis and subsequently antioxidant activities. These results illustrated that each mechanism possibly relies on different molecular size and/or peptide composition and sequence to give the specific antioxidant activity ( $\mathrm{Wu}$ et al., 2003; Cheung et al., 2012).

Table 3 and 4 revealed effects of substrate concentration and hydrolysis time, respectively on antioxidant activities and protein content of protein hydrolysates. All responses increased with increasing substrate content and time of digestion. Contrarily, a decline trend of metal chelating ability was distinguished when hydrolysis time increased (Table 4) implying that this property fades when the peptides size was decreased upon hydrolysis time. A similar trend found in protein hydrolysates from defatted salmon backbones (Slizyte et al., 2016). The akin correlations among those factors and responses were also observed in the principal component analysis (PCA) (Figure 2). It can be concluded that the APH produced at $1.2 \%$ substrate concentration and $60 \mathrm{~min}$ hydrolysis possessed great antioxidant activities with the highest protein content.

\subsection{Principal component analysis}

PCA was performed to know how the production factors; protein type (4 levels), substrate concentration (5 levels) and hydrolysis time (6 levels) were correlated to antioxidant capacity of the protein hydrolysates. Dimensional distribution of all 
Table 3. Effect of substrate concentration on antioxidant activities and protein content of protein hydrolysates.

\begin{tabular}{|c|c|c|c|c|c|}
\hline & & & oncentr & & \\
\hline & 0.4 & 0.6 & 0.8 & 1.0 & 1.2 \\
\hline $\begin{array}{l}\text { ABTS } \\
\left(\mathrm{mg} \mathrm{TE}^{2} / 100 \mu \mathrm{g} \text { protein }\right)\end{array}$ & $1.17^{\mathrm{d}}$ & $1.37^{c}$ & $1.76^{\mathrm{b}}$ & $1.88^{\mathrm{b}}$ & $3.00^{\mathrm{a}}$ \\
\hline $\begin{array}{l}\text { Lipophilic-ORAC } \\
\text { (mg TE/100 } \mu \text { g protein) }\end{array}$ & $0.41^{\mathrm{d}}$ & $0.60^{\mathrm{cd}}$ & $0.71^{b c}$ & $0.86^{\mathrm{ab}}$ & $0.99^{\mathrm{a}}$ \\
\hline Protein content $(\mathrm{mg} / \mathrm{ml})$ & $2.80^{\mathrm{e}}$ & $4.26^{\mathrm{d}}$ & $5.41^{c}$ & $6.60^{b}$ & $7.93^{\mathrm{a}}$ \\
\hline
\end{tabular}

${ }^{1}$ Each value is the average of each measurement analyzed from all protein types and hydrolysis times at the same substrate level. Different letters within each row indicate a significant difference $(\mathrm{P}<0.05)$ among treatments. ${ }^{2} \mathrm{TE}$ : Trolox equivalent.

Table 4. Effect of time of hydrolysis on antioxidant activities and protein content of protein hydrolysates.

\begin{tabular}{|c|c|c|c|c|c|c|}
\hline & & & Time of & $\sin _{(\mathrm{min})}{ }^{1}$ & & \\
\hline & 0 & 5 & 10 & 15 & 30 & 60 \\
\hline $\begin{array}{l}\text { ABTS } \\
\left(\mathrm{mg} \mathrm{TE}^{2} / 100 \mu \mathrm{g} \text { protein }\right)\end{array}$ & $1.57^{c}$ & $1.60^{\mathrm{c}}$ & $1.79^{\mathrm{bc}}$ & $1.88^{b}$ & $1.98^{\mathrm{b}}$ & $2.20^{\mathrm{a}}$ \\
\hline $\begin{array}{l}\text { Hydrophilic-ORAC } \\
\text { (mg TE/100 } \mu \text { g protein) }\end{array}$ & $1.02^{\mathrm{c}}$ & $1.65^{\mathrm{b}}$ & $1.83^{\mathrm{ab}}$ & $1.94^{\mathrm{ab}}$ & $1.93^{\mathrm{ab}}$ & $2.00^{\mathrm{a}}$ \\
\hline $\begin{array}{l}\text { Lipophilic-ORAC } \\
\text { (mg TE/100 } \mu \text { g protein) }\end{array}$ & $0.39^{b}$ & $0.69^{a}$ & $0.76^{\mathrm{a}}$ & $0.80^{\mathrm{a}}$ & $0.81^{\mathrm{a}}$ & $0.84^{\mathrm{a}}$ \\
\hline $\begin{array}{l}\text { Metal chelating ability } \\
\text { (mg EDTA/100 } \mu \text { g protein) }\end{array}$ & $1.31^{\mathrm{a}}$ & $0.91^{\mathrm{b}}$ & $0.77^{b c}$ & $0.69^{b c}$ & $0.62^{c}$ & $0.60^{\mathrm{c}}$ \\
\hline Protein content $(\mathrm{mg} / \mathrm{ml})$ & $4.36^{\mathrm{d}}$ & $4.73^{\mathrm{cd}}$ & $5.34^{\mathrm{bc}}$ & $5.60^{a-c}$ & $6.10^{\mathrm{ab}}$ & $6.30^{\mathrm{a}}$ \\
\hline
\end{tabular}

${ }^{1}$ Each value is the average of each measurement analyzed from all protein types and substrate levels at the same hydrolysis time. Different letters within each row indicate a significant difference $(\mathrm{P}<0.05)$ among treatments. ${ }^{2} \mathrm{TE}$ : Trolox equivalent.

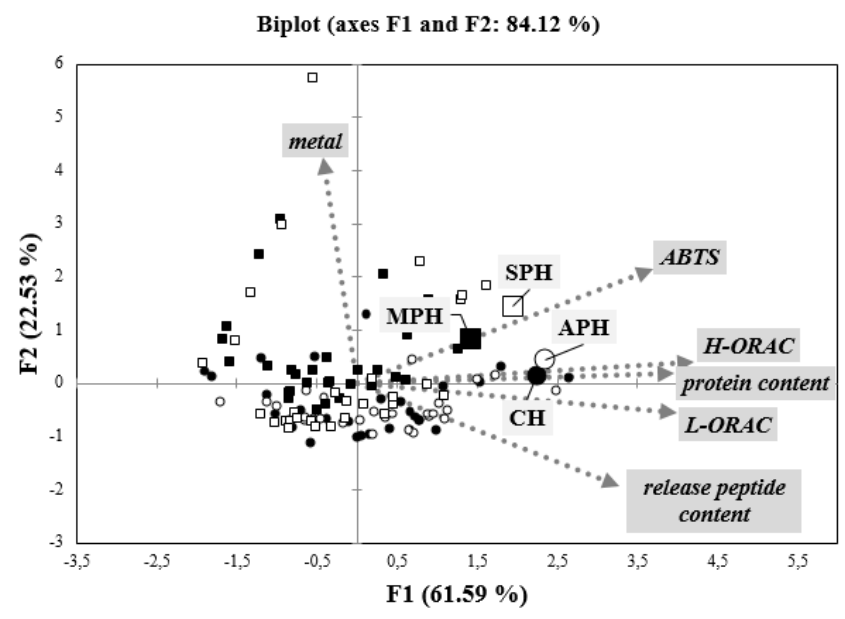

Figure 2. Principal component analysis (PCA) on the measured parameters ABTS, ORAC and metal chelating ability of protein hydrolysates affected by protein type, substrate concentration and time of hydrolysis. Freeze dried minced fillet hydrolysate $(\mathrm{CH})$ (solid circle), alkali-aided protein hydrolysate (APH) (open circle), myofibrillar protein hydrolysate (MPH) (solid square), and sarcoplasmic protein hydrolysate (SPH) (open square). Enlarged symbols represent hydrolysates of each protein obtained at $1.2 \%$ substrate concentration and 60 min hydrolysis time. ABTS: ABTS radical scavenging activity; H-ORAC and L-ORAC: oxygen radical absorbance capacity in water and fat, respectively; metal: metal chelating ability.
120 treatments can be clustered according to their similarities and differences using PCA. Different antioxidant activities of samples were then grouped allowing understanding the predominant samples with high antioxidant potency.

Principal component (PC) plot (Figure 2) comprises of two main axes explaining $84.1 \%(\mathrm{PC} 1=61.6$ and $\mathrm{PC} 2=22.5 \%)$ of the antioxidant capacity, protein content, and release of peptide fragments. It was noted that PC1 was associated positively with parameters which reflected hydrolysis of various tilapia proteins as protein content, release of peptides, as well as with antioxidant capacities (ABTS, hydrophilic-ORAC, and lipophilic-ORAC). While PC2 was associated positively with only metal chelating ability. Furthermore, it was evident that hydrophilic-ORAC, lipophilic-ORAC, and protein content were related with each other. The $\mathrm{APH}$ and $\mathrm{CH}$ especially at $1.2 \%$ substrate concentration and 60 min hydrolysis, which exhibited the highest antioxidant activities (ABTS and lipophilic-ORAC for $\mathrm{APH}$ and hydrophilic-ORAC for $\mathrm{CH}$ ) closely located among most of attribute vectors in the biplot), indicating positive influence on the dependent components of PC1 i.e. hydrophilic-ORAC, lipophilic-ORAC, and protein content. Thus, their antioxidant activities were primarily caused by peptides with peroxyl radical quenching ability. Whereas, MPH and SPH were appeared near ABTS vector. Oppositely, less samples were located in the same quadrant (upper left) with metal chelating ability, which was 
isolated from other attribute vectors exhibiting that most protein hydrolysates were less associated with chelating mechanism. These results demonstrated that the APH exhibited comparative antioxidant abilities to the $\mathrm{CH}$. The results were in consistent with the results obtained from ANOVA analysis.

\section{Conclusions}

Antioxidant activities of protein hydrolysates produced from tilapia byproducts significantly influenced by protein type, substrate concentration and hydrolysis time. The alkaline-aided protein hydrolysate $(\mathrm{APH})$ demonstrated comparative antioxidant activity to the control (hydrolysate from tilapia fillet), which was more proficient than the myofibrillar and sarcoplasmic protein hydrolysates. The APH's antioxidant activity was highly related to peptides with peroxyl radical quenching ability. Therefore, the potential of APH as the alternative natural antioxidant may be applied in food products. Nevertheless, identification of antioxidant peptides and their mechanisms are needed to be further investigated.

\section{Acknowledgements}

The authors would like to thank the Higher Education Research Promotion and National Research University Project of Thailand, Office of the Higher Education Commission, through the Food and Functional Food Research Cluster of Khon Kaen University (PhD-54115) for the scholarship and research fund. The authors thank Mr. Peter Bint for assistance with the English language presentation.

\section{References}

Arnao, M., Cano, A., \& Acosta, M. (2001). The hydrophilic and lipophilic contribution to total antioxidant activity. Food Chemistry, 73(2), 239-244. http://dx.doi.org/10.1016/S0308-8146(00)00324-1.

Association of Official Analytical Chemists - AOAC. (1999). Official Methods of Analysis (16th ed.). Washington: Association of Official Analytical Chemist.

Boyer, R. F., \& Mccleary, C. J. (1987). Superoxide ion as a primary reductant in ascorbate-mediated ferritin iron release. Free Radical Biology \& Medicine, 3(6), 389-395. http://dx.doi.org/10.1016/08915849(87)90017-7. PMid:2828195.

Cao, G. H., \& Prior, R. L. (1999). Measurement of oxygen radical absorbance capacity in biological samples. Oxidants and antioxidants. Methods in Enzymology, 299, 50-62. http://dx.doi.org/10.1016/ S0076-6879(99)99008-0. PMid:9916196.

Chen, X.X., Hu, X., Li, L.H., Yang, X.Q., Wu, Y.Y., Lin, W.L., Zhao, Y.Q., Ma, H.X. \& Wei, Y. (2015). Antioxidant properties of tilapia component protein hydrolysates and the membrane ultrafiltration fractions. Advanced Materials Research, 1073-1076, 1812-1817. http://dx.doi.org/10.4028/www.scientific.net/amr.1073-1076.1812

Cheung, I. W. Y., Cheung, L. K. Y., Tan, N. Y., \& Li-Chan, E. C. Y. (2012). The role of molecular size in antioxidant activity of peptide fractions from Pacific hake (Merluccius productus) hydrolysates. Food Chemistry, 134(3), 1297-1306. http://dx.doi.org/10.1016/j. foodchem.2012.02.215. PMid:25005946.

Chi, C. F., Hu, F. Y., Wang, B., Li, Z. R., \& Luo, H. Y. (2015). Influence of amino acid compositions and peptide profiles on antioxidant capacities of two protein hydrolysates from Skipjack tuna (Katsuwonus pelamis) dark muscle. Marine Drugs, 13(5), 2580-2601. http:// dx.doi.org/10.3390/md13052580. PMid:25923316.

Dekkers, E., Raghavan, S., Kristinsson, H. G., \& Marshall, M. R. (2011). Oxidative stability of mahi mahi red muscle dipped in tilapia protein hydrolysats. Food Chemistry, 124(2), 640-645. http:// dx.doi.org/10.1016/j.foodchem.2010.06.088.

Dyer, W. J., French, H. V., \& Snow, J. M. (1950). Proteins in fish muscle. I. Extraction of protein fraction in fresh fish. Journal of the Fisheries Research Board of Canada, 7(10), 585-593. http:// dx.doi.org/10.1139/f47-052.

Fryer, H. J., Davis, G. E., Manthorpe, M., \& Varon, S. (1986). Lowry protein assay using an automatic microtiter plate spectrophotometer. Analytical Biochemistry, 153(2), 262-266. http://dx.doi. org/10.1016/0003-2697(86)90090-4. PMid:3706709.

García-Moreno, P. J., Batista, I., Pires, C., Bandarra, N. M., EspejoCarpio, F. J., Guadix, A., \& Guadix, E. M. (2014). Antioxidant activity of protein hydrolysates obtained from discarded Mediterranean fish species. Food Research International, 65, 469-476. http://dx.doi. org/10.1016/j.foodres.2014.03.061.

Hoyle, N. T., \& Merritt, J. H. (1994). Quality of fish protein hydrolysates from herring (Clupea harengus). Journal of Food Science, 59(1), 76-79. http://dx.doi.org/10.1111/j.1365-2621.1994.tb06901.x.

Hraš, A. R., Hadolin, M., Knez, Ž., \& Bauman, D. (2000). Comparison of antioxidative and synergistic effects of rosemary extract with a-tocopherol, ascorbyl palmitate and citric acid in sunflower oil. Food Chemistry, 71(2), 229-233. http://dx.doi.org/10.1016/ S0308-8146(00)00161-8.

Huang, D., Ou, B., Hampsch-Woodill, M., Flanagan, J. A., \& Prior, R. L. (2002). High-throughput assay of oxygen radical absorbance capacity using a multichannel liquid handing system coupled with a Microplate fluorescence reader in 96-well format. Journal of Agricultural and Food Chemistry, 50(16), 4437-4444. http:// dx.doi.org/10.1021/jf0201529. PMid:12137457.

Hultin, H. O., \& Kelleher, S. D. (1999). U.S. Pat. No. 6,005,073. Process for isolating a protein composition from a muscle source and protein composition. Advanced Protein Technologies Inc.

Nelson, D. L., \& Cox, M. M. (2001). Lehninger Principles of Biochemistry (3rd ed.). New York: Worth Publisher Inc. http:// dx.doi.org/10.1007/978-3-662-08289-8.

Slizyte, R., Rommi, K., Mozuraityte, R., Eck, P., Five, K., \& Rustad, T. (2016). Bioactivities of fish protein hydrolysates from defatted salmon backbones. Biotechnology Reports, 11, 99-109. http://dx.doi. org/10.1016/j.btre.2016.08.003. PMid:28352546.

Subdivision of Research and Analysis of Fisheries Statistics (2017). Nile tilapia production statistics. Thailand: Fisheries Development Policy and Strategy Division, Department of Fisheries, Ministry of Agriculture and Cooperatives. Retrieved from https://www. fisheries.go.th/strategy/UserFiles/files/tilapia\%206-60(1).pdf

Toopcham, T., Mes, J. J., Wichers, H. J., Roytrakul, S., \& Yongsawatdigul, J. (2017). Bioavailability of angiotensin I-converting enzyme (ACE) inhibitory peptides derived from Virgibacillus halodenitrificans SK13-7 proteinases hydrolyzed tilapia muscle proteins. Food Chemistry, 220, 190-197. http://dx.doi.org/10.1016/j.foodchem.2016.09.183. PMid:27855889.

Wachirattanapongmetee, K., Thawornchinsombut, S., Pitirit, T., Yongsawatdigul, J., \& Park, J. W. (2009). Functional properties of 
protein hydrolyses prepared from alkali-aided protein extraction of hybrid catfish frame. Trends in Food Science \& Technology, 1, 71-81.

Wang, H., Zhang, F., Cao, J., Zhang, Q., \& Chen, Z. (2013). Proteolysis characteristics of sarcoplasmic, myofibrillar, and stromal proteins separated from grass carp and antioxidant properties of their hydrolysates. Food Science and Biotechnology, 22(2), 531-540. http://dx.doi.org/10.1007/s10068-013-0111-z.

Wu, H. C., Chen, H. M., \& Shiau, C. Y. (2003). Free amino acids and peptides as related to antioxidant properties in protein hydrolysates of mackerel (Scomber austriasicus). Food Research International, 36(9-10), 949-957. http://dx.doi.org/10.1016/S0963-9969(03)00104-2. 